\title{
UPAYA KELUARGA DALAM MENJAGA PERTUNANGAN ANAK PERSPEKTIF BIMBINGAN KONSELING KELUARGA
}

\author{
Syaifatul Jannah \\ Institut Dirosat Islamiyah Al-Amien Prenduan Sumenep \\ Email: syaifatuljannah95@gmail.com
}

\begin{abstract}
Abstrak: Penelitian ini bertujuan untuk mendeskripsikan upaya keluarga dalam menjaga pertunangan anak perspektif BK keluarga di Desa Kaduara Barat Kecamatan Larangan Kabupaten Pamekasan. Penelitian ini menggunakan metode kualitatif dengan jenis penelitian deskriptif kulitatif karena peneliti ingin menggali secara mendalam tentang upaya keluarga dalam menjaga pertunangan anak perspektif BK keluarga baik dari segi pelaksanaannya maupun hasil akhir dari upaya tersebut. Temuan penelitian ini adalah upaya keluarga untuk mempertahankan pertunangan anaknya di Desa Kaduara Barat dilaksanakan dengan mengadakan pertemuan keluarga ke dua belah pihak pada hari-hari besar Islam seperti hari raya Idul fitri dan Idul Adha dan pada saat pasangan yang bertunangan tersebut sedang dihadapkan pada suatu permasalahan atau pada kesempatan baik lainnya. Dalam perspektif BK keluarga, pelaksanaannya menggunakan metode eklektik dengan langkah-langkah yang peneliti kaitkan dengan langkah-langkah bimbingan dan konseling keluarga pada umumnya, yakni pengembangan rapport, pengembangan apresiasi emotional, pengembangan alternative modus perilaku, fase membina hubungan konseling, dan feed back. Pelaksanaan bimbingan dan konseling keluarga untuk menjaga pertunangan di Desa Kaduara Barat lebih ditekankan pada tahap pengembangan alternative modus perilaku dan fase membina hubungan konseling. Hasil akhir pelaksanaan bimbingan dan konseling keluarga yang dilakukan oleh anggota keluarga ke dua belah pihak ini dikategorikan berhasil, karena telah ada rencana bagi pasanganpasangan yang bertunangan untuk menikah setelah menyelesaikan studi S-1 nya dan kini bagi pasangan suami istri itu menikah setelah melalui masa pertunangan yang lama. Sehingga dapat dikatakan pula bahwa peran keluarga dalam memberikan bimbingan kepada anak-anak mereka yang bertunangan untuk mempertahankan hubungan pertunangan hingga menikah ini sangat kuat dan memberikan pengaruh besar.
\end{abstract}

Kata Kunci: Pertunangan, Bimbingan Konseling Keluarga 


\begin{abstract}
This research aims to describe the family's efforts to defend child's engagement in the perspective of family counseling in Kaduara Barat village Larangan subdistrict Pamekasan Regency. This research used qualitative method with kind of qualitative descriptive research, because this researcher wanna discuss as deepen about the family's efforts to defend child's engagement in the perspective of family counseling in in Kaduara Barat village Larangan subdistrict Pamekasan Regency from its implementation side and the result from these efforts. The finding of this research is family's efforts to defend child's engagement in Kaduara village was brought about in with holding family meeting both of sides. When big days of Islamic are as like Idul Fitri feast day and Idul Adha feast day. And when engaged couples were being faced to a problem or the other good opportunity. in the perspective of family counseling, its implementation used eclectic method by steps which the researcher connected with guidance steps and family counseling commonly. The last result is there both of sides were categorized success because it had been planning for couple who engaged to marry after finishing undergraduated program and now a days wife-husband couples married after passed long engagement moment. So that it can be said also that family action to give guidance to their children who engaged to defend engagement relationship till married. This is so strong and giving big influence.
\end{abstract}

Keywords: Guidance and Family Counseling, engagement

\title{
Pendahuluan
}

Pada dasarnya manusia adalah makhluk sosial yang mau tidak mau akan terus hidup secara bersamaan antara satu sama lain. Kehidupan sosial ini akan terus mendorong manusia saling mengisi antara satu dengan yang lain. Keterkaitan ini menjadi dasar seseorang untuk terus berhubungan dan bertautan antara satu dengan yang lain. Salah satu keterkaitan ini adalah mempersatukan tali silaturrahmi dua insan sosial dalam sebuah ikatan suci yaitu perkawinan. Hal ini dijelaskan dalam Q.S An-Nur (24): 32.

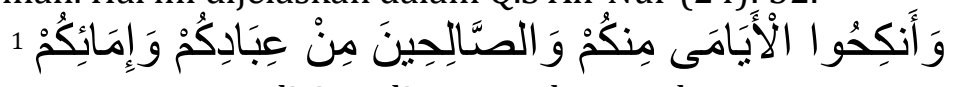

"Dan kawinkanlah orang-orang yang sendirian di antara kamu, dan orang-orang yang layak (berkawin) dari hamba-hamba sahayamu yang lelaki dan hamba-hamba sahayamu yang perempuan."

Suatu perkawinan biasanya didahului oleh suatu keadaan pendahuluan, yang mempunyai sifat khusus dan yang paling umumnya dinamakan pertunangan. Pertunangan berasal dari bahasa arab yaitu khitbah. ${ }^{2}$ Dalam hukum islam, pertunangan dikenal dengan lafal khitbah, dalam terminology arab memiliki akar kata yang sama dengan al-khitab dan al-khathab. Al-khatab berarti "pembicaraan". Apabila dikatakan takhataba maksudnya "dua orang yang sedang berbincang-bincang". Jika dikatakan khatabahu fi amr artinya "ia memperbincangkan sesuatu persoalan pada seseorang". Jika khitbah (pembicaraan) ini berhubungan dengan ihwal perempuan, maka makna yang pertama kali ditangkap adalah pembicaraan yang berhubungan dengan persoalan pernikahannya. ${ }^{3}$ Secara istilah, khitbah adalah permintaan seseorang laki-laki untuk

\footnotetext{
1Yayasan Penyelenggara Penterjemah Alquran, Al-Quran dan Terjemahannya, (Semarang: PT. Tanjung Mas Inti, 1992), hal. 549.

${ }^{2}$ Ahmad Warson, Kamus Al-Munawir, (Surabaya: Pustaka Progessif, 1997), hal. 349.

${ }^{3}$ Cahyadi Takariawan, Izinkan Aku Meminangmu, (solo: Era Intermedia, 2004), hal. 23.
} 
menguasai seorang perempuan tertentu dari keluarganya dan bersekutu dalam urusan kebersamaan hidup. ${ }^{4}$

Madura merupakan sebuah daerah yang kaya akan tradisi dan budaya. Salah satu tradisi dikalangan masyarakat Madura yang masih melekat hingga saat ini ialah pertunangan, yaitu sebuah proses awal yang dilalui oleh dua pasangan atau dua insan yang akan menikah. Termasuk juga di Desa Kaduara Barat, Tradisi penyatuan dua insan ini merupakan ciri khas dari masyarakat Kaduara Barat itu sediri. Keadaan pertunangan ini ada, apabila pihak laki-laki dan pihak perempuan telah setuju untuk melakukan perkawinan dan tentunya maksud tujuan ini didahului dengan suatu lamaran, yaitu permintaan pihak laki-laki kepada pihak perempuan untuk dijadikan pasangan hidup. Hal ini juga disebut dengan meminang.

Meminang maksudnya pihak laki-laki meminta kepada pihak perempuan untuk menjadi istrinya dengan cara-cara yang sudah umum berlaku di tengah-tengah masyarakat. Meminang termasuk usaha pendahuluan dalam rangka perkawinan. Allah SWT menggariskan agar masing-masing pasangan yang mau kawin, lebih dulu saling mengenal sebelum dilakukan akad nikahnya sehingga pelaksanaan perkawinannya nanti benar-benar berdasarkan pandangan dan penilaian yang jelas. ${ }^{5}$

Di Desa Kaduara Barat Kecamatan Larangan Kabupaten Pamekasan, Pertunangan dua insan ini terjadi baik karena dijodohkan oleh orang tua maupun hasil sendiri (pacaran). Dalam tradisi Madura, para orang tua mengkhitbahkan putra putrinya selama waktu kesepakatan yang disepakati ketika awal pertunangan. Tak sedikit masyarakat Madura mengkhitbahkan anak mereka selama kurang lebih 4 tahun. Hal ini terjadi karena tak jarang dari para orang tua mengkhitbahkan anak-anak mereka sejak anak-anak mereka masih berada di pondok pesantren atau masih melanjutkan studinya.

Uniknya dalam masa pertunangan, masyarakat Desa Kaduara Barat memiliki kebiasan "Metraeh dan Nyaleneh". Metraeh berarti membayarkan zakat, sedangkan Nyaleneh berarti menggantikan baju. Dalam masa pertunangan pihak laki-laki membayarkan zakat dan memberi baju baru kepada pihak perempuan terutama ketika bulan Ramadhan. Hal ini sudah menjadi kebiasaan bagi yang bersangkutan yang dimaksudkan agar hubungan kedua belah pihak tetap terjaga. Kebiasaan ini sudah mengakar kuat dikalangan Desa Kaduara Barat. Namun untuk menjaga hubungan pertunangan tersebut tentunya tidak hanya dengan Metraeh dan Nyaleneh, akan tetapi juga didukung dengan beberapa faktor yang berhubungan dengan peran keluarga masing-masing, salah satunya yaitu dengan sering dilakukannya silaturrahmi.

Di Desa Kaduara Barat, masyarakatnya sangat menjunjung tinggi nilai-nilai keIslaman. Islam menganjurkan bahwa masa pertunangan tidak lebih dari 3 bulan. Akan tetapi realita yang ada di Desa Kaduara Barat bahwa masih banyak masyarakat yang menjalankan pertunangan dengan waktu yang relatif lama. Pertunangan ini dipertahankan karena bertujuan untuk mengenal pribadi masing-masing dan telah membudaya di kalangan masyarakat Desa Kaduara Barat bertunangan dengan waktu yang relatif lama untuk menuju ke pelaminan (menikah), hal ini disebabkan karena masyarakat Desa Kaduara Barat melakukan pertunangan sejak masih di bawah umur. Tidak ada keyakinan atau kepercayaan tertentu yang menyebabkan masyarakat Desa Kaduara Barat melakukan pertunangan dengan waktu yang lama, hanya saja ini merupakan budaya turun temurun dari para tetua mereka.

\footnotetext{
${ }^{4}$ Abdul Aziz Muhammad Azzam, Abdul Wahhab Sayyed Hawwas, Fiqih Munakahat, (Jakarta: Amzah, 2011), hal. 8.

5 Sayyid Sabiq, Fikih Sunah 6 (Bandung: Al-Ma'arif, 1990), hal. 10.
} 


\section{DIROSAT \\ Journal of Islamic Studies \\ Volume 6, No. 22021}

ISSN: 2541-1667 (print); 2541-1675 (online)

Sebagai gambaran umum, akan peneliti paparkan sedikit tentang masa pertunangan di Desa Kaduara Barat kecamatan Larangan Kabupaten Pamekasan, terdapat dua pasangan, TR dan FT yang sudah menjalani pertunangan kurang lebih 6 tahun yaitu dari tahun 2010-sekarang. Keduanya dijodohkan oleh kedua orang tua mereka, karena kebetulan mereka berdua masih memiliki hubungan keluarga. TR dan FT mengatakan bahwa terjaganya hubungan pertunangan yang begitu lama tersebut karena adanya saling kepercayaan diantara mereka dan selalu melakukan silaturrahmi setiap kali ada kesempatan, terutama di hari-hari besar islam, seperti bulan ramadhan, lebaran, dan lainlain. Pada pertemuan ini TR "Metraeh dan Nyaleneh" FT. Selain itu pada silaturrahmi ini terjadilah sebuah perbincangan antara keluarga kedua belah pihak berupa nasehatnasehat yang diberikan oleh kepala keluarga agar bisa mempertahankan pertunangan mereka sampai tiba waktu menikah. Pada pertemuan itu juga diisi dengan menceritakan hal-hal yang disukai dan tidak disukai oleh masing-masing kedua pasangan tersebut, sehingga bisa dikatakan bahwa pertemuan ini merupakan tahap pendekatan atau mengenal lebih dalam dari masing-masing kedua pasangan.

Pertemuan silaturrahmi tersebut dalam dunia konseling, dikenal dengan istilah Bimbingan dan Konseling Keluarga. Bimbingan dan Konseling Keluarga atau Family therapy merupakan upaya bantuan yang diberikan kepada individu sebagai bagian dari anggota keluarga melalui sistem keluarga (pembenahan komunikasi keluarga) agar potensinya berkembang seoptimal mungkin dan masalahnya dapat diatasi atas dasar kemauan membantu dari semua anggota keluarga berdasarkan kerelaan dan kecintaan terhadap keluarga. ${ }^{6}$ Farid Mashudi mengemukakan bahwa Family Therapy (Konseling keluarga) merupakan proses bantuan kepada individu dengan melibatkan para anggota keluarga lainnya dalam upaya menyelesaikan masalah yang dialami. ${ }^{7}$

Menurut perez yang dikutip oleh sofyan wilis, konseling keluarga (family therapy) yaitu suatu proses interaktif untuk membantu keluarga dalam mencapai keseimbangan dimana setiap anggota keluarga merasakan kebahagiaan. Di Desa Kaduara Barat, Silaturrahmi yang dilakukan oleh kedua belah pihak yang bertunangan, merupakan suatu proses interaktif untuk mencapai keseimbangan dan kebahagiaan sehingga hubungan pertunagan tersebut bisa terjaga dan bertahan lama sampai tiba waktu untuk menikah.

Selain pengertian-pengertian di atas Sofyan Wilis juga berpendapat bahwa konseling keluarga adalah usaha membantu individu anggota keluarga untuk mengaktualisasikan potensinya atau mengantisipasi masalah yang dialaminya, melalui sistem kehidupan keluarga, dan mengusahakan agar terjadi perubahan perilaku yang positif pada diri individu yang akan memberikan dampak positif pula terhadap keluarga lainnya.

Bimbingan keluarga juga membantu individu yang akan berkeluarga memahami tugas dan tanggung jawabnya sebagai anggota keluarga sehingga individu siap menghadapi kehidupan berkeluarga. Bagi masyarakat di Desa Kaduara Barat Bimbingan dan konseling keluarga perlu dilakukan untuk bisa memberikan arahan dan penguatan kepada kedua belah pihak yang bertunangan sehingga pertunangan mereka tetap terjaga dan nantinya dapat berlanjut pada tahap akad (menikah). Masyarakat Desa Kaduara Barat memiliki cara tersendiri dalam upaya memberikan bimbingan dan konseling keluarga kepada kedua pihak yang bertunangan untuk bisa mempertahankan pertunangan mereka.

\footnotetext{
${ }^{6}$ Sofyan S. willis, Konseling Keluarga (Bandung: ALFABETA, 2008), hal. 83.

7 Farid Mashudi, Psikologi Konseling (Yogjakarta: IRCiSoD, 2012) hal. 241.
} 


\section{Metode Penelitian}

Penelitian ini menggunakan pendekatan kualitatif. Pendekatan ini dipilih untuk mendapatkan data kualitatif yang objektif dan mendalam yang nantinya data hasil penelitian tersebut dapat disajikan secara urut, detail dan mendalam. Sedangkan penelitian kualitatif menurut Bogdan dan Tailor seperti yang dikutip Lexy J. Moleong yaitu sebagai prosedur penelitian yang menghasilkan data deskriptif berupa kata-kata tertulis atau lisan dari orang-orang dan perilaku yang diamati.8 Dalam penelitian ini peneliti ingin mengetahui secara mendalam mengenai upaya keluarga dalam menjaga pertunangan anak mereka di Desa Kaduara Barat Kecamatan Larangan Kabupaten Pamekasan perspektif bimbingan dan konseling keluarga.

Sedangkan jenis penelitian menggunakan deskriptif kualitatif. Penelitian deskriptif kualitatif bertujuan memperoleh informasi-informasi mengenai keadaaan yang ada pada saat ini tidak menguji hipotesa atau tidak menggunakan hipotesa melainkan hanya mendeskripsikan informasi apa adanya sesuai dengan variabel-variabel yang diteliti. ${ }^{9}$

Penelitian deskriptif kualitatif yaitu penelitian yang bertujuan untuk menggambarkan dengan kata-kata yang objektif dan mendalam yang nantinya data hasil penelitian tersebut dapat disajikan secara deskriptif sehingga temuan hasil penelitian tersaji secara urut, detail dan mendalam. Penelitian deskriptif kualitatif bertujuan untuk menggambarkan, meringkaskan berbagai kondisi, berbagai situasi, atau berbagai fenomena realitas sosial yang ada dimasyarakat yang menjadi objek penelitian, dan berupaya menarik realitas itu ke permukaan sebagai suatu ciri, karakter, sifat, model, tanda, atau gambaran tentang kondisi, situasi, ataupun fenomena tertentu. ${ }^{10}$

Dalam penelitian ini peneliti akan mendeskripsikan secara mendalam hasil data yang diperoleh melalui observasi dan wawancara kepada para pasangan yang telah bertunangan dan para pasangan suami istri yang pernah bertunangan.

Subyek dalam penelitian ini yaitu pasangan yang masih bertunangan dan pasangan suami istri yang pernah bertunangan di Desa Kaduara Barat Kecamatan Larangan Kabupaten Pamekasan. Subyek ini ditentukan dengan pertimbangan sebagai berikut: Pertama, pasangan yang bertunangan maksimal 2 tahun dan minimal 10 bulan. Kedua, pasangan suami istri yang pernah melalui masa pertunangan maksimal 2 tahun dan minimal 10 bulan. Ketiga, pasangan yang masih bertunangan dan pasangan suami istri yang telah melalui masa pertunangan pernah mengalami konflik, baik konflik ringan maupun berat selama berada dalam masa pertunangan tersebut. Keempat, pasangan yang masih bertunangan dan pasangan suami istri yang telah melalui masa pertunangan menyelesaikan konflik dengan melibatkan keluarga.

Untuk mengumpulkan data pada penelitian ini, peneliti menggunakan teknik sebagai berikut: Observasi, wawancara mendalam (In Depth Interview), dan dokumentasi. Observasi yang digunakan pada penelitian ini adalah observasi nonpartisipatif, Karena peneliti tidak terlibat dan hanya sebagai pengamat independen. Peneliti mencatat, menganalisis dan selanjutnya dapat membuat kesimpulan tentang model bimbingan dan konseling keluarga untuk mempertahankan pertunangan di Desa Kaduara Barat Kecamatan Larangan Kabupaten Pamekasan. Adapun wawancara mendalam (In Depth

\footnotetext{
8 Lexy J. Moleong, Metodologi Penelitian Kualitatif (Bandung: Remaja Rosdakarya, 2007), hal. 3.

9 Mardalis, Metode Penelitian Suatu Pendekatan Proposal (Jakarta: Bumi Aksara, 1995), hal. 26.

10 Burhan Bungin, Penelitian Kualitatif, (Jakarta: Kencana Prenada Media Group, 2007), hal. 68
} 


\section{DIROSAT \\ Journal of Islamic Studies \\ Volume 6, No. 22021}

ISSN: 2541-1667 (print); 2541-1675 (online)

Interview) dalam penelitian ini peneliti berusaha mencari data sebanyak mungkin melalui wawancara terhadap para informan, terutama informan kunci. Peneliti berupaya mengajukan pertanyaan sedetail mungkin tentang model bimbingan dan konseling keluarga untuk mempertahankan pertunangan di Desa Kaduara Barat Kecamatan Larangan Kabupaten Pamekasan. Sedangkan dokumentasi merupakan catatan peristiwa yang sudah berlalu. dokumen bisa berbentuk tulisan, gambar, atau karya-karya monumental dari seseorang. ${ }^{11}$ Dokumen yang berbentuk tulisan misalnya catatan harian, sejarah kehidupan, ceritera, biografi, peraturan kebijakan. Dokumen yang berbentuk gambar misalnya foto, gambar hidup, sketsa, dan lain-lain. dokumen yang berbentuk karya misalnya karya seni yang dapat berupa gambar, patung, film, dan lain-lain. Studi dokumen merupakan pelengkap dari penggunaan metode observasi dan wawancara dalam penelitian kualitatif.

Adapun teknik analisa data dalam penelitian ini menggunakan metode analisis kualitatif. Metode kualitatif adalah cara penelitian yang menghasilkan data deskriptif analisis, yaitu apa yang dinyatakan oleh responden secara tertulis atau lisan dan perilakunya yang nyata diteliti dan dipelajari sebagai suatu yang utuh. Dari hasil tersebut kemudian ditarik suatu kesimpulan yang merupakan jawaban atas permasalahan yang diangkat dalam penelitian ini. ${ }^{12}$

Miles and Huberman mengemukakan bahwa aktivitas dalam analisa data kualitatif dilakukan secara interaktif dan berlangsung secara terus menerus sampai tuntas, sehingga datanya jenuh. Analisa terdiri dari 3 alur kegiatan yang terjadi secara bersamaan, yaitu: reduksi data (data reduction), penyajian data (data display), dan kesimpulan (conclution drawing).

\section{Pembahasan dan Hasil Penelitian}

Di Desa Kaduara Barat pasangan yang telah bertunangan biasanya mampu mempertahankan hubungan pertunangan mereka dalam jangka waktu yang cukup lama, misalnya 10 bulan, 1 tahun, 2 tahun, bahkan ada yang mencapai hingga 6 tahun. Dalam tradisi Madura khususnya masyarakat di Desa Kaduara Barat terdapat hal-hal yang boleh dilakukan dan tidak boleh dilakukan baik laki-laki maupun perempuan yang bertunangan selama berada dalam masa pertunangan.

Hal yang boleh dilakukan diantaranya yaitu:

1. Tradisi Metraeh dan Nyaleneh

2. Komunikasi melalui Handphone

3. Melakukan pertemuan keluarga

Menurut Pak Ahmad, hal tersebut di atas bersifat fleksibel, karena ada sebagian pasangan yang tidak melakukan semua yang disebutkan di atas dengan alasan-alasan tertentu. Misalnya alasan karena salah satu pihak tidak ingin memberatkan pihak yang lain dengan mengeluarkan biaya hanya untuk Metraeh dan Nyaleneh. Dan alasan karena masing-masing pasangan masih berada di Pondok Pesantren, sehingga memungkinkan untuk tidak melakukan komunikasi melalui Handphone. Adapun hal yang tidak boleh dilakukan adalah sebagaimana aturan dalam Islam yaitu:

1. Berkhalwat (bersepi-sepi berdua) dengan tunangannya tanpa sepengetahuan pihak keluarga.

2. Bertemu, berjalan, atau berboncengan berdua dengan laki-laki atau perempuan lain yang bukan tunangannya tanpa sepengetahuan kleuarga.

\footnotetext{
11 Sugiyono, Metode Penelitian Kuantitatif Kualitatif R\&D (Bandung: Alfabeta, 2008), hal. 240.

12 Soerjono Soekanto, Metodologi Penelitian Hukum (Jakarta: UI Press, 1986), h. 10.
} 
Menurut Pak Ahmad apabila hal ini dilakukan maka akan diberikan teguran langsung oleh pihak keluarga dan langsung dimintai pertanggung jawaban mereka melakukan hal demikian melalui musayawarah dengan ke dua pihak keluarga. Biasanya yang menjadi solusi ialah langsung menikah atau membatalkan pertunangan.

Dalam upaya mempertahankan hubungan pertunangan hingga tiba waktu untuk menikah, masyarakat Desa Kaduara barat selalu melibatkan keluarga mereka di samping hanya adanya komitmen dari masing-masing pasangan.

Tabel 1

Upaya keluarga menjaga pertunangan anak Pembahasan

\begin{tabular}{|c|c|c|c|c|}
\hline $\begin{array}{l}\text { Nama } \\
\text { Pasangan } \\
\text { (Inisial) }\end{array}$ & $\begin{array}{c}\text { Masa } \\
\text { Pertunangan }\end{array}$ & $\begin{array}{c}\text { Upaya } \\
\text { keluarga }\end{array}$ & $\begin{array}{c}\text { Waktu } \\
\text { Pelaksanaan }\end{array}$ & $\begin{array}{c}\text { Anggota keluarga } \\
\text { terlibat }\end{array}$ \\
\hline A dan $\mathrm{R}$ & 1 tahun & $\begin{array}{l}\text { Pertemuan } \\
\text { keluarga }\end{array}$ & $\begin{array}{l}\text { Hari raya } \\
\text { Islam }\end{array}$ & $\begin{array}{c}\text { Bapak A dan R, ibu A } \\
\text { dan R, kakak A dan R R, } \\
\text { kakak ipar A dan R }\end{array}$ \\
\hline $\mathrm{H}$ dan $\mathrm{L}$ & 2 tahun & $\begin{array}{l}\text { Pertemuan } \\
\text { keluarga }\end{array}$ & $\begin{array}{l}\text { Hari raya } \\
\text { Islam }\end{array}$ & $\begin{array}{c}\text { Bapak L, Ibu H dan L, } \\
\text { Paman H dan L, Kakek L, } \\
\text { Kakak H dan L, Kakak } \\
\text { Ipar H }\end{array}$ \\
\hline $\mathrm{K}$ dan $\mathrm{F}$ & 1 tahun & $\begin{array}{l}\text { Pertemuan } \\
\text { keluarga }\end{array}$ & $\begin{array}{l}\text { Hari raya } \\
\text { Islam }\end{array}$ & $\begin{array}{c}\text { Bapak K, Ibu K, Nenek K, } \\
\text { Paman K dan F, kakek F, } \\
\text { Kakak F, Bibi F }\end{array}$ \\
\hline I dan S & 10 Bulan & $\begin{array}{l}\text { Pertemuan } \\
\text { keluarga }\end{array}$ & $\begin{array}{l}\text { Hari raya } \\
\text { Islam }\end{array}$ & $\begin{array}{c}\text { Bapak I, Ibu I dan S, } 3 \\
\text { saudara perempuan I, } \\
\text { Kakak Laki-laki S, Kakak } \\
\text { Ipar S, Paman dan Bibi S }\end{array}$ \\
\hline
\end{tabular}

Pelaksanaan bimbingan dan konseling keluarga di Desa Kaduara Barat untuk mempertahankan pertunangan dilakukan ketika hari-hari besar Islam dan ketika pasangan yang bertunangan tersebut sedang menghadapi suatu permasalahan yang serius. Bimbingan dan konseling keluarga ini dilakukan dengan cara mengadakan pertemuan antar keluarga ke dua belah pihak yang bertunangan.

Dalam pelaksanaannya dihadiri oleh anggota keluarga yang memiliki peranan aktif dalam memberikan nasehat-nasehat kepada individu yang bertunangan, baik dari keluarga pihak perempuan dan keluarga pihak laki-laki. Diantaranya adalah Bapak, Ibu, Saudara dan Saudari, Kakek, Nenek, Paman, dan Bibi. Dan yang sering dijadikan pemimpin atau dalam bahasa konselingnya yaitu konselor adalah anggota keluarga yang dipandang mampu untuk memberikan nasehat terbaik serta memiliki keilmuan yang lebih. Biasanya yaitu orang tertua diantara anggota keluarga lainnya dan biasanya pula memiliki peranan aktif dalam masyarakat di Desanya.

Dari hasil wawancara dan observasi yang dilakukan kepada narasumber, mayoritas dari mereka mengatakan bahwa yang menjadi konselor yakni orang yang memimpin pada pertemuan keluarga tersebut adalah tokoh agama atau tokoh masyarakat yang juga merupakan anggota keluarga mereka. 


\section{DIROSAT \\ Journal of Islamic Studies \\ Volume 6, No. 22021}

ISSN: 2541-1667 (print); 2541-1675 (online)

Adapun metode yang digunakan yaitu secara eklektik, karena baik orang yang memimpin pertemuan (Konselor) dan anggota keluarga yang lain sama-sama berperan aktif. ${ }^{13}$ Tahap-Tahap yang digunakan juga bersifat fleksibel, Artinya masih dapat berubahubah. Dalam hal ini peneliti mengaitkan dengan tahap-tahap konseling keluarga di bawah ini, yaitu:

a. Pengembangan Rapport

Hubungan konseling pada tahap awal seharusnya diupayakan. pengembangan raport merupakan suasana hubungan konseling yang akrab, jujur, saling percaya, sehingga menimbulkan keterbukaan diri klien. Tujuan utama teknik ini adalah untuk menjembatani hubungan antara konselor dengan klien, sikap penerimaan dan minat yang mendalam terhadap klien dan masalahnya. ${ }^{14}$

Tahap ini diawali dengan saling menanyakan kabar masing-masing anggota keluarga yang hadir yang dipimpin oleh sang Bapak dari anak yang bertunangan. Hal ini dilakukan dengan tujuan agar masing-masing anggota keluarga tersebut merasa nyaman dan tidak terlalu serius (tegang). Selain itu, masing-masing anggota keluarga saling melakukan maaf-maafan terlebih dahulu, karena memang pertemuan keluarga ini sering dilakukan pada waktu hari raya Idul Fitri atau Idul Adha.

Tahap awal ini juga dilakukan dengan bahasa lisan yang sopan, halus dan ramah, karena selain untuk membuat semua anggota keluarga merasa nyaman, juga karena adanya kesadaran sikap saling menghormati antar sesama keluarga, baik keluarga pria maupun keluarga wanita.

\section{b. Pengembangan Apresiasi Emotional}

Munculnya kemampuan untuk menghargai perasaan masing-masing anggota keluarga, dan keinginan mereka agar masalah yang mereka hadapi dapat terselesaikan semakin besar. Muncul dinamika interaksi dari semua individu yang terlibat dalam konseling. Ada dua teknik konseling keluarga yang afektif yaitu sculpting.

Tahap ke dua ini Bapak pihak pria meminta kepada anak-anak mereka untuk menceritakan perkembangan hubungan pertunangan mereka. Mereka menjawab bahwa saat ini hubungan mereka baik-baik saja, namun terkadang ada kesalah pahaman kecil yang terjadi diantara mereka.

Pada Pertemuan ini pula, anak-anak mereka ditanyakan mengenai kesiapan mereka untuk menuju ke pernikahan, serta diminta untuk menceritakan kesulitankesulitan yang dihadapi selama menjalin hubungan. Rata-rata dari mereka mengatakan bahwa mereka kesulitan dalam mengontrol sifat kekanak-kanakan dan egois dalam diri masing-masing.

c. Pengembangan Alternative Modus Perilaku

Dalam tahap ini, baik konseli maupun anggota keluarga mengembangkan dan melatihkan perilaku-perilaku baru yang disepakati berdasarkan hasil diskusi dalam konseling. Aplikasi perilaku tersebut dapat dilakukan melalui praktik dirumah. Mungkin konselor memberi suatu daftar perilaku baru yang akan diterapkan selama satu minggu, kemudian melaporkannya pada sesi konseling keluarga berikutnya. Tugas tersebut disebut juga home assigmant (pekerjaan rumah). ${ }^{15}$

\footnotetext{
13 Sofyan S.Wilis, Konseling Keluarga (Family Counseling) (Bandung: ALFABETA, 2008)

14 Makmun Khoironi, Psikologi Konseling (Yogyakarta: Aswaja Pressindo, 2014), hal 84.

15 Sulistyarini dan Mohammad Jauhar, Dasar-Dasar Konseling (Jakarta: Prestasi Pustaka, 2014), hal. 250-251.
} 
Tahap ke tiga ini anak-anak yang bertunangan diberikan nasehat dan masukan mengenai perkembangan hubungan keduanya. Salah satu isi nasihat yang diberikan yaitu: "Kalian berdua harus tetap menjaga kepercayaan dan setia tanpa harus seringsering bertemu, serta sebisa mungkin untuk tetap menjaga kesucian diri masing-masing karena di zaman sekarang ini sudah marak terjadi kasus muda mudi hamil di luar nikah".

Nasehat ini diberikan agar bisa diterapkan oleh anak-anak mereka sehingga keduanya dapat mempertahankan hubungan pertunangan mereka hingga tiba nanti masa untuk menikah.

\section{d. Fase Membina Hubungan Konseling}

Tahap ini Bapak pihak pria menanyakan kepada anak-anak mereka yang menjalin pertunangan mengenai kesanggupan mereka untuk saling menjaga kepercayaan dan tidak saling bertemu. Anak-anak mereka sepakat mengatakan bahwa mereka sepenuhnya patuh terhadap orang tua dan keluarga.

Pada tahap ini juga keluarga memberikan solusi mengenai kesulitan-kesulitan yang dialami oleh anak-anak mereka selama menjalin hubungan pertunangan.

Salah satunya ialah dengan memberikan nasihat: "Perbaiki sikap kekanakkanakan itu, karena hal itu adalah salah satu kunci untuk mencapai kebahagiaan kelak ketika berumah tangga". Selanjutnya: "Kalian berdua sudah sama-sama dewasa, di antara kalian berdua harus saling tertanam sifat memaafkan dan menerima, karena kamu sendiri yang memilih dia untuk menjadi pasanganmu, jadi jangan sampai mengecewakan keluarga kalian masing-masing dan jangan sampai hubungan kalian ini kandas, karena ini sudah mau hampir 1 tahun hubungan pertunangan kalian".

\section{Penutup}

Berdasarkan hasil penelitian yang dilakukan peneliti mengenai model bimbingan dan konseling keluarga untuk mempertahankan pertunangan di Desa Kaduara Barat Kecamatan Larangan Kabupaten Pamekasan maka dapat diambil kesimpulan bahwa pelaksanaan bimbingan dan konseling keluarga untuk mempertahankan pertunangan di desa kaduara barat kecamatan larangan kabupaten pamekasan lebih ditekankan pada tahap ke tiga, yaitu tahap pengembangan alternative modus perilaku dan tahap ke empat, yaitu fase membina hubungan konseling seperti yang dialami oleh narasumber dalam penelitian ini. Hasil pelaksanaan bimbingan dan konseling keluarga untuk mempertahankan pertunangan yaitu dilihat dari penuturan setiap narasumber yang menjadi objek dalam penelitian ini mengatakan bahwa bagi pasangan yang belum menikah, mereka akan menikah setelah menyelesaikan S-1 nya. Adapun bagi pasangan suami istri yang telah melewati masa pertunangan yang lama, kini mereka telah menjalani kehidupan rumah tangga dengan bahagia dan penuh syukur. Jadi dapat disimpulkan bahwa dalam pemberian bimbingan dan konseling keluarga yang dilakukan oleh anggota keluarga ke dua belah pihak dapat dikatakan berhasil, karena telah ada rencana bagi pasangan-pasangan yang bertunangan untuk menikah setelah menyelesaikan studi S-1 nya dan kini bagi pasangan suami istri itu menikah setelah melalui masa pertunangan yang lama. Sehingga dapat dikatakan pula bahwa peran keluarga dalam memberikan bimbingan kepada anak-anak mereka yang bertunangan untuk mempertahankan 


\section{DIROSAT \\ Journal of Islamic Studies \\ Volume 6, No. 22021}

ISSN: 2541-1667 (print); 2541-1675 (online)

hubungan pertunangan hingga menikah ini sangat kuat dan memberikan pengaruh besar, karena jika tidak, maka hubungan pertunangan tersebut pastinya telah berakhir di tengah jalan atau tidak sampai pada pernikahan. Keterlibatan keluarga dalam memberikan nasehat dan bimbingan kepada pasangan yang bertunangan mampu membawa hubungan pertunangan mereka dalam waktu yang lama bahkan sampai pada pernikahan.

Saran penelitian ini diajukan kepada pihak keluarga, pihak pasangan yang bertunangan, pihak pasangan suami istri, dan kepada peneliti. Kepada pihak keluarga hendaknya memberikan bimbingan dan konseling keluarga yang lebih intensif dengan mendatangkan konselor yang benar-benar berkompeten dalam bimbingan dan konseling keluarga. Hal ini dapat memberi pemahaman yang lebih luas terkait kehidupan keluarga, permasalahan, serta solusi dari permasalahan tersebut, sehingga tumbuh semangat dan pemahaman yang jelas bagi mereka yang sedang berada dalam masa pertunangan ini dalam mempertahankan hubungan pertunangan mereka atau mengambil keputusan untuk menikah. Selanjutnya, kepada pihak pasangan yang bertunangan hendaknya benar-benar mengikuti bimbingan dan konseling keluarga dengan baik untuk mempertahankan pertunangan dan untuk mendapatkan ilmu atau nasehatnasehat baik terkait kehidupan berkeluarga. Kemudian, kepada pihak pasangan suami istri yang telah melalui masa pertunangan yang lama hendaknya lebih menghargai satu sama lain dan belajar, serta mengambil hikmah baik dari pengalaman-pengalaman selama berada dalam masa pertunangan agar tercipta keluarga yang sakinah, mawaddah, wa rahmah. Terakhir, kepada peneliti hendaknya lebih mendalami lagi tentang tema penelitian ini agar dapat mengaplikasikannya, mengingat bimbingan dan konseling keluarga yang dilakukan oleh orang-orang yang benar-benar berkompeten masih jarang ada di Desa Kaduara Barat itu sendiri.

\section{Daftar Pustaka}

Abdul Aziz Muhammad Azzam, Abdul Wahhab Sayyed Hawwas. 2011. Fiqih Munakahat. Jakarta: Amzah.

Bungin, Burhan. 2007. Penelitian Kualitatif. Jakarta: Kencana Prenada Media Group.

Jauhar, Mohammad, dan Sulistyarini. 2014. Dasar-Dasar Konseling. Jakarta: Prestasi Pustaka.

Khoironi, Makmun. 2014. Psikologi Konseling. Yogyakarta: Aswaja Pressindo

Mardalis. 1995. Metode Penelitian Suatu Pendekatan Proposal. Jakarta: Bumi Aksara.

Mashudi, Farid. 2012. Psikologi Konseling. Yogjakarta: IRCiSoD.

Moleong, Lexy J. 2007. Metodologi Penelitian Kualitatif, edisi revisi. Bandung: Remaja Rosdakarya.

Sabiq, Sayyid. 1990. Fikih Sunah 6. Bandung: Al-Ma'arif.

Soekanto, Soerjono. 1986. Metodologi Penelitian Hukum. Jakarta: UI Press. 
Sugiyono, 2008. Metode Penelitian Kuantitatif, Kualitatif dan $R \& D$. Bandung: Alfabeta.

Takariawan, Cahyadi. 2004. Izinkan Aku Meminangmu. Solo: Era Intermedia. Warson, Ahmad. 1997. Kamus Al-Munawir. Surabaya: Pustaka Progessif.

Willis, Sofyan S. 2008. Konseling Keluarga. Bandung: ALFABETA.

Yayasan Penyelenggara Penterjemah Alquran. 1992. Al-Quran dan Terjemahannya. Semarang: PT. Tanjung Mas Inti. 